\title{
Criterion for the Cost-Effectiveness of Aircraft Engines Conversion
}

\author{
Ajupov A. A. ${ }^{1}$, Kurilova A. A. ${ }^{2} \&$ Ivanov D. U. ${ }^{3}$ \\ ${ }^{1}$ Kazan Federal University, Institute of Management, Economics and Finance, Kazan, Russia \\ ${ }^{2}$ Togliatti State University, Togliatti, Russia \\ ${ }^{3}$ Samara State Aerospace University, Samara, Russia \\ Correspondence: Ivanov D. U., Samara State Aerospace University, Samara, 443086, Russia. Tel: \\ 7-917-122-3879. E-mail: aakurilova@yandex.ru
}

Received: December 27, 2014 Accepted: February 19, 2015 Online Published: April 30, 2015

doi:10.5539/ass.v11n11p12 URL: http://dx.doi.org/10.5539/ass.v11n11p12

\begin{abstract}
This article discusses the technical and economic efficiency of conversion of gas-turbine engines for use in various industries. Russian aircraft engine production capacity is not able to meet the needs of gas turbine engines for terrestrial applications. The only solution to this situation is the conversion of aircraft engine exhaust their flight hours. We propose a criterion for the relative economic efficiency of aircraft engines conversion, allowing to select the most appropriate type of engine based on its characteristics.
\end{abstract}

Keywords: aircraft engine conversion, costs, economic efficiency, efficiency criterion of conversion

\section{Introduction}

In today's challenging economic environment created by the enterprises of aviation engine, urgent problem using them for the needs of the national economy. Already have experience in the application of gas turbine engines (GTE) not only in the propulsion of airplanes and helicopters, but also in land-based applications.

Wide practical implementation got pumping units with gas turbine drives of different capacities. The operation of such plants on natural gas showed high efficiency, reliability and durability of the turbine drive. Gas turbine engines can be successfully used as a driving electric power plants. Experience in operating power plants with GTE showed that operating costs 50\% less than the cost of the operation of a diesel or turbine installation.

Currently, the Russian engine-building enterprises produced 100 GTE land destination in the year, and the demand of the Russian economy is much higher. Until 2025 for the refurbishment of existing pumping stations and the creation of new infrastructure will need a gas complex to 2300 GTE. Approximately the same number of new facilities required for thermal power plants in different regions of the country.

To one of the most promising ways to solve this problem include the following:

1. Enable capacities aviation companies to develop and manufacture GTE land use.

2. Use with certain modifications GTE, spent flight hours on the aircraft to continue their use in terrestrial plants to produce disposable technical resource.

Obviously, the second direction from the economic point of view is more promising. However, on the way to solve this problem is a problem of economic evaluation measures for converting GTE compared to the cost of creating a new engine for ground use.

The analysis shows that the development of the new engine requires significant capital investment, profitability of the project is shown only after the start of operation of serial machines. Obtaining the required return is possible to provide only 5 to 7 years. In comparison with the new development activities for converting GTE pay off in 32 months from the start of design work, which is more than twice as fast. That is why the task of converting aircraft gas turbine engines for use in terrestrial conditions is relevant for its implementation requires the development of special methods and means of economic justification.

\section{Theory}

After selecting the desired base engine should determine the amount of work required to convert it, the possibility of its implementation, and estimated costs. Based on a comprehensive analysis of the selected parent engine, the results of the feasibility study can begin to develop the project and its implementation. 
In this paper formed selection algorithm specifications when converting GTE depending on the characteristics of the base engine and the anticipated operating conditions, consisting of three stages:

- Phase selection of characteristics that provide resource GTE.

- Phase selection of characteristics to ensure maintainability.

- Phase selection of characteristics that provide environmental characteristics (reduction of noise, emissions) GTE.

After a preliminary determination of a set of technical nature, it is necessary to stick to assess the feasibility of improvements in economic terms.

To solve this problem, you can suggest the criterion of the relative cost-effectiveness of interventions for conversion of gas turbine engines:

$$
\mathrm{K}_{A G T E}=\left\{\begin{array}{l}
\sum_{i=1}^{n} \frac{\alpha_{i} \cdot Z_{i}}{\beta_{i} \cdot X_{i}} \rightarrow \min , \\
\mathrm{X}=\left\{\mathrm{x}_{1}, \mathrm{x}_{2}, \ldots, \mathrm{x}_{n}\right\}, \quad 1 \leq i \leq n, \\
\alpha_{i} \in[1 ; 10], \quad \beta_{i} \in(0 ; 1]
\end{array}\right.
$$

where $\kappa_{A G T E}$ - criterion of the relative cost-effectiveness of interventions for conversion of aircraft engines, rub.; $X_{i}$ - details of specifications for the characteristics of $X, \mathrm{MW}, \mathrm{mg} / \mathrm{m}^{3}, \mathrm{~kg} / \mathrm{h}, \mathrm{h}$, etc .;

$\alpha_{i}$ - coefficient reflecting the rise in the cost of measures to ensure the required quantitative measure of the $i$-th technical characteristics;

$\beta_{i}$ - coefficient taking into account the extent to which a quantitative measure of the $i$-th technical characteristics of the base engine requirements to its quantitative measure after the intervention by converting, $1 / \mathrm{MW}, \mathrm{m}^{3} / \mathrm{mg}, \mathrm{h} / \mathrm{kg}, 1 / \mathrm{h}$, etc.;

$Z_{i}$ - nominal costs of implementing the $i$-th characteristic, rub.;

$n$ - number of characteristics.

Coefficients $\alpha_{i}$ and $\beta_{i}$ appointed as a result of the expert panel's assessment on the events of conversion. Their numerical value is set on the stage of development of technical specifications. Accordingly, the composition of the expert committee should include representatives from the customer's representatives and representatives of the developer of the engine production plant immediately implement measures to conversion.

It should be noted that the introduction in to the consideration ratio $\beta_{i}$ necessary to normalize the relevant technical specifications.

The nominal value of the cost $Z_{i}$ taken equal to the value of the restoration costs a quantitative measure of the $i$-th performance at the overhaul base engine.

\section{Results}

Consider the application of developed criteria on example. Assume that the base engine is assumed to choose (from several hypothetical models) to convert it, and draw a conclusion about the feasibility of bringing a quantitative measure of the basic technical characteristics of the engine to the requirements specification. Table 1 shows the values of the basic technical characteristics of the engine and required their value for a convertible engine.

Table 1. Technical characteristics of engines

\begin{tabular}{|c|c|c|c|}
\hline \multirow{2}{*}{ Characteristic, $X_{i}$} & \multicolumn{2}{|c|}{ Base engine } & \multirow{2}{*}{$\begin{array}{c}\text { Convertible } \\
\text { engine }\end{array}$} \\
\hline & 1 & 2 & \\
\hline Assigned resource, th. $\mathrm{H}$. & $-^{*}$ & 19 & 100 \\
\hline Thrust (for the base engine), kN; output (for a convertible engine), MW & $190 / 16$ & $180 / 16$ & 16 \\
\hline Efficiency, \% & 32 & 29 & 36 \\
\hline Kind of fuel & Kerosene & Kerosene & Natural gas \\
\hline \multicolumn{4}{|c|}{$\begin{array}{l}\text { The content of harmful substances in emissions } \mathrm{mg} / \mathrm{m}^{3} \text { (reduced to } 15 \% \\
\qquad \mathrm{O}_{2} \text { ): }\end{array}$} \\
\hline NOx & 170 & 173 & 150 \\
\hline $\mathrm{CO}$ & 320 & 310 & 300 \\
\hline
\end{tabular}

Note: $*$ - the engine is operated on a technical condition within the assigned resources of main parts. 
In practice accounted for about 20-30 specifications, such as fuel consumption, speed rotor (s), the time the engine is started and the time of its release to the nominal mode, and others. This example illustrates the performance of the proposed criterion, we restrict the main of them.

On the basis of the data in Table 1 expert committee assigns the corresponding coefficients $\alpha_{i}$ and $\beta_{i}$ and fills out a form in a Table 2 .

When completing the Table 2 in this paper was made the following assumption $-\alpha_{i}$ coefficients were determined as the ratio of $1 / \beta_{i}$, ie more expensive measures to ensure the required quantitative measure of the $i$-th technical characteristics inversely the extent to which a quantitative measure of the $i$-th technical characteristics of the base engine requirements for its quantitative measure after conversion. As stipulated above, in practice the coefficients $\alpha_{i}$ appointed expert committee on the basis of experience and statistics on holding similar events could differ materially from those in the present example.

Table 2. The results of expert evaluation

\begin{tabular}{|c|c|c|c|c|}
\hline \multirow{2}{*}{ Characteristic, $X_{i}$} & \multicolumn{2}{|c|}{$\alpha_{i}$} & \multicolumn{2}{|c|}{$\beta_{i}$} \\
\hline & Engine 1 & Engine 2 & Engine 1 & Engine 2 \\
\hline Assigned resource, th. $1 / \mathrm{H}^{*}$ & $4-5,26$ & 5,26 & $0,19-0,25$ & 0,19 \\
\hline $\begin{array}{l}\text { Thrust (for the base engine), } \mathrm{kN} \text {; output (for a } \\
\text { convertible engine) } 1 / \mathrm{MW}^{*}\end{array}$ & 1 & 1 & 1 & 1 \\
\hline Efficiency, $1 / \% *$ & 1,13 & 1,24 & 0,89 & 0,81 \\
\hline Kind of fuel & \multicolumn{4}{|c|}{$\begin{array}{l}\text { In } К_{\text {Агтд criteria are taken into account only the costs of }} \\
\text { completion of the fuel system to ensure that its work on } \\
\text { gaseous fuels }\end{array}$} \\
\hline \multicolumn{5}{|l|}{$\begin{array}{l}\text { The content of harmful substances in emissions } \mathrm{m}^{3} / \mathrm{mg}^{*} \\
\text { (reduced to } 15 \% \mathrm{O}_{2} \text { ): }\end{array}$} \\
\hline NOx & 1,15 & 1,18 & 0,87 & 0,85 \\
\hline $\mathrm{CO}$ & 1,07 & 1,03 & 0,93 & 0,97 \\
\hline
\end{tabular}

Note: $*$ - dimension refers to the coefficient $\beta_{i}$

For example, while determining the coefficient $\kappa_{A G T E}$ we will make another assumption - assume that the nominal costs of providing the $i$-th technical specifications are the same for any $X_{i}$ and are 350 thousand rubles. respectively. Then we obtain:

$$
\begin{gathered}
\mathrm{K}_{A G T E}^{1}=\frac{4 \cdot 350}{0,25 \cdot 100}+\frac{1 \cdot 350}{1 \cdot 16}+\frac{1,13 \cdot 350}{0,89 \cdot 36}+350+\frac{1,15 \cdot 350}{0,87 \cdot 150}+\frac{1,07 \cdot 350}{0,93 \cdot 300}==0,445 \text { million. rub .; } \\
\mathrm{K}_{A G T E}^{2}=\frac{5,26 \cdot 350}{0,19 \cdot 100}+\frac{1 \cdot 350}{1 \cdot 16}+\frac{1,24 \cdot 350}{0,81 \cdot 36}+350+\frac{1,18 \cdot 350}{0,85 \cdot 150}+\frac{1,03 \cdot 350}{0,97 \cdot 300}==0,488 \text { million.rub. }
\end{gathered}
$$

Thus, the results of the calculation of the criterion can be seen that it is advisable to choose as the base engine 1 . Further, based on the data in Table 2, the expert commission decides whether to bring all of the features in it to the desired value and the immediate implementation phase begins the conversion process.

\section{Conclusions}

Developed and presented in this article, the criterion of the relative cost-effectiveness of interventions for conversion of aircraft engines allows the initial assessment phase to carry out selection of the base engine of the plurality of aircraft engines, to convert it, and to determine the feasibility of providing a particular characteristic in the process of converting a concrete base engine.

Moreover, this test allows you to:

- To evaluate the amount of work to change the basic design of the engine;

- Determine the proportion of the cost of completion of a particular structural element in the overall cost structure of the outputs;

- disclose the effectiveness of a particular revision. 
Criterion of the relative cost-effectiveness of interventions for aircraft engines conversion can be useful for MOTORS organizations in determining the scope of work to finalize the design of the base engine in the process of conversion. Also it can be used in determining the cost of works to ensure specific technical characteristics.

The results of this research can be used: by customers for independent technical and economic evaluation of the effectiveness of project financing GTE conversion from its own resources in accordance with their own needs; by investors who are interested in investing long-term programs; performers who are interested in creating a competitive product for the order of the consumer; by project organizations for the development of technical solutions for the renewal of production capacities, which are used aircraft engines.

\section{References}

Ardayfio, D. D. (2000). Principles and Practices of Design Innovation. Original Research Article Technological Forecasting and Social Change, 64(2-3), 155-169. http://dx.doi.org/10.1016/S0040-1625(99)00108-0

Curran, R., Raghunathan, S., \& Price, M. (2004). Review of aerospace engineering cost modelling: The genetic causal approach. Review Article Progress in Aerospace Sciences, 40(8), 487-534 http://dx.doi.org/10.1016/ j.paerosci.2004.10.001

Ismagilov, I. I. (2006). An approach to ordering of systems of the Walsh discrete functions. Radioelectronics and Communications Systems, 49(1), 46-50.

Ismagilov, I. I. (2010). Oblique generalizations of the Walsh basis. Radioelectronics and Communications Systems, 53(12), 625-635. http://dx.doi.org/10.3103/S0735272710120010

Kirshin I. A. (2014a). Modeling the long-term trend of accumulation of knowledge. Life Science Journal, 11(6s), 482-486.

Kirshin, I. A. (2014b). Ecological restrictions of modern economic growth. Studies on Russian Economic Development, 25(3), 276-282. http://dx.doi.org/10.1134/S1075700714030046

Kirshin, I. A., \& Kuzminov, S. V. (2014). Evaluation method development for regional economies competitiveness. Mediterranean Journal of Social Sciences, 5(18), 159-164

Lee, J. J. (2010). Can we accelerate the improvement of energy efficiency in aircraft systems? Original Research Article Energy Conversion and Management, 51(1), 189-196 http://dx.doi.org/10.1016/j.enconman.2009.09. 011

Lee, J. J., Lukachko, S. P., \& Waitz, I. A. (2004). Aircraft and Energy Use. Reference Module in Earth Systems and Environmental Sciences, from Encyclopedia of Energy, 29-38

McDonald, C. F., \& Wilson, D. G. (1996). The utilization of recuperated and regenerated engine cycles for high-efficiency gas turbines in the 21st century. Review Article Applied Thermal Engineering, 16(8-9), 635-653. http://dx.doi.org/10.1016/1359-4311(95)00078-X

Najjar, Y. S. H., Akyurt, M., Al-Rabghi, O. M., \& Alp, T. (1993). Cogeneration with gas turbine engines. Original Research Article Heat Recovery Systems and CHP, 13(5), 471-480. http://dx.doi.org/10.1016/ 0890-4332(93)90048-Z

Nkoi, B., Pilidis, P., \& Nikolaidis, T. (2013). Performance of small-scale aero-derivative industrial gas turbines derived from helicopterengines. Original Research Article Propulsion and Power Research, 2(4), 243-253. http://dx.doi.org/10.1016/j.jppr.2013.11.001

Sun, Z.-G. (2008). Energy efficiency and economic feasibility analysis of cogeneration system driven by gas engine. Original Research Article Energy and Buildings, 40(2), 126-130

Turan, O., \& Aydin, H. (2014). Exergetic and exergo-economic analyses of an aero-derivative gas turbine engine. Original Research Article Energy, 74(1), 638-650.

\section{Copyrights}

Copyright for this article is retained by the author(s), with first publication rights granted to the journal.

This is an open-access article distributed under the terms and conditions of the Creative Commons Attribution license (http://creativecommons.org/licenses/by/3.0/). 